\title{
A Case from Australia's War CRIMES TRIALS: LIEUTENANT-GENERAL NISHIMURA, 1950
}

\section{LISA LEE*}

\begin{abstract}
In the aftermath of World War II, Australia undertook domestic trials of suspected Japanese war criminals between 1945 and 1951. This article focuses on Australia's war crimes trial of Lieutenant-General Nishimura as held at the Los Negros court in mid-June 1950, and the subsequent petitioning period and confirmation process. The Australian war crimes courts were military courts vested with broad discretionary powers that facilitated the expeditious trials of accused. The procedure of war crimes courts differed from that of field general courts-martial in two main areas: admissible evidence and sentencing range - and this article highlights concomitant problems arising during the trial and subsequent case on review. This article examines the prosecution of the case entirely on documentary evidence; the impact of low admissibility thresholds for evidence; issues regarding the voluntariness and reliability of witness evidence; and the option of capital punishment in the Nishimura trial.
\end{abstract}

\section{INTRODUCTION}

Lieutenant-General Nishimura Takuma ${ }^{1}$ was General Officer Commanding of the Konoe Division of the Japanese Imperial Army. ${ }^{2}$ During the Japanese invasion of the Pacific region, Nishimura and his Imperial Guard Division troops had engaged in the Battle of Muar, in Malaya. ${ }^{3}$ An Australian and Indian composite force, including members of the $2 / 29^{\text {th }}$ Battalion, $65^{\text {th }}$ Battery and $45^{\text {th }}$ Indian Brigade, had to withdraw towards Yong Peng en route

\footnotetext{
${ }^{*}$ LLB (Hons), BA (Hons) (Monash). SJD candidate, Faculty of Law, Monash University. This article is derived from the author's honours dissertation in History-Politics. The author is indebted to her former supervisor, Dr Julie Fenley, for her generous support, meticulous reading of drafts, and invaluable feedback. The author would also like to thank the anonymous reviewers, and the editors of the Deakin Law Review, for the helpful comments.

${ }^{1}$ In this article, Japanese names are cited surname first, and without macrons.

${ }^{2}$ National Archives of Australia ('NAA'): A471, 81942 - Record of Military Court — Nishimura and Nonaka.

${ }^{3}$ Gilbert Mant, Massacre at Parit Sulong (Kangaroo Press, 1995) 14-15.
} 
to Parit Sulong. ${ }^{4}$ The Japanese forces had captured the bridge at Parit Sulong, ${ }^{5}$ and the ensuing attacks forced the retreat of the Australian and Indian soldiers. The wounded were left behind and, on 22 January 1942, fell victim to what would become known as the Parit Sulong massacre. ${ }^{6}$ Approximately 110 Australian and 35 to 40 Indian soldiers were captured by the Japanese. ${ }^{7}$ The already injured prisoners of war were then inhumanely treated, deprived of water and medical aid, beaten, tortured, humiliated, assaulted with rifle butts and bayoneted before being executed by mass shootings and then cremated by Japanese soldiers. ${ }^{8}$ Some of the prisoners of war were burned alive, as not all had perished before the firing squad.

Nishimura was charged with ordering the massacre and, in mid-June 1950, he was brought before the Australian war crimes court situated in Los Negros. ${ }^{9}$ Nishimura's co-accused in the trial was his personal aide, Captain Nonaka Shoichi. This article will focus exclusively on aspects of the trial pertaining to Nishimura. Due to the disturbing accounts of torture and murder during the Parit Sulong massacre, and to the facts that the majority of the victims were Australian, the total deceased numbered in excess of 150 persons, and Nishimura was a senior Japanese commander, this trial remains the most controversial of all the Manus Island proceedings. Strongly divergent opinions were expressed about the Nishimura trial at the time. Similarly, in subsequent analyses commentators have argued both for and against Nishimura's guilt. ${ }^{10}$

${ }^{4}$ NAA: A471, 81942 - Record of Military Court - Nishimura and Nonaka, Précis of Evidence. See, eg, Lynette Silver, The Bridge at Parit Sulong: An Investigation of Mass Murder, Malaya 1942 (The Watermark Press, 2004).

${ }^{5}$ Mant, above n 3, 21; Silver, above n 4, 176.

${ }^{6}$ NAA: A471, 81942 - Record of Military Court - Nishimura and Nonaka, Précis of Evidence. See also Mant, above n 3, 7. The prosecution outlined this version of the events leading up to, and during, the massacre at Nishimura's trial.

${ }^{7}$ NAA: A471, 81942 - Transcript of Proceedings — Nishimura and Nonaka, Closing Address of Prosecution.

${ }^{8}$ NAA: A471, 81942 - Affidavit of Ben Charles Hackney dated 12 November 1945. See also Mant, above n 3, 25-67 for Hackney's extended account of the massacre.

${ }^{9}$ Although, strictly speaking, the Los Negros court was situated adjacent to Manus Island, the trials at the Los Negros court are commonly referred to as the 'Manus Island trials', as they are in this article. The Los Negros court hosted the final set of Australia's war crimes trials. See, eg, George Dickinson, 'Japanese War Trials' (1952) 24(2) The Australian Quarterly 69, 69; Sir Gerard Brennan, 'Foreword' in Yuki Tanaka, Tim McCormack and Gerry Simpson (eds), Beyond Victor's Justice? The Tokyo War Crimes Trials Revisited (Martinus Nijhoff, 2011) xi, xi-xii.

${ }^{10}$ See, eg, Ian Ward, Snaring the Other Tiger (Media Masters, 1996), wherein the author presents a hypothesis of Nishimura's innocence and the alleged partiality of the Australian government's motivations in pursuing Nishimura. Commentators have criticised Ward's accusations against James Godwin and the author's reliance on James MacKay's fictitious sources. See Gregory Hadley and James Oglethorpe, 'MacKay’s Betrayal: Solving the 
In the immediate post-World War II period, the Australian government enacted specific legislation to facilitate its domestic war crimes trials. The War Crimes Act 1945 (Cth) ('War Crimes Act') was based on the British Royal Warrant 1945. ${ }^{11}$ The War Crimes Act provided the legal framework for the war crimes courts and their applicable jurisdiction, rules of evidence and sentencing range. ${ }^{12}$ Australian military courts, convened pursuant to the War Crimes Act, were authorised to try accused charged with war crimes against any persons who had resided in Australia, British subjects, or citizens of Allied powers, from a period commencing on 2 September $1939 .^{13}$ The War Crimes Act was supplemented by the Regulations for the Trial of War Criminals 1945 (Cth) ('War Crimes Regulations'). ${ }^{14}$ The War Crimes Regulations further determined the composition of the courts, the appointment of judges-advocate, court procedure including that governing petitions by accused, and the powers of authorities to confirm, remit or commute sentences. ${ }^{15}$ The war crimes trials were to be conducted expeditiously. ${ }^{16}$ Trials

Mystery of the "Sado Island Prisoner-of-War Massacre”' (2007) 71 The Journal of Military History 441. Views on Nishimura and the Parit Sulong massacre which diverge from Ward's are enunciated by two other authors, Gilbert Mant and Lynette Silver: Mant, above n 3; Silver, above n 4. Whilst Ward argues that Nishimura was innocent, Mant's book includes an extended version of Hackney's account of the Parit Sulong massacre and Silver offers various counter-arguments in response to Ward's suppositions. George Dickinson's historical articles provide firsthand perspectives on the trials, from the viewpoint of a Defence Advisory Officer. In regard to the Nishimura trial, Dickinson is of the opinion that Nishimura's guilt was proven to the court's satisfaction and likened the Parit Sulong massacre to Napoleon's massacre [of the Turks] at Alexandria: Dickinson, 'Japanese War Trials', above n 9; George Dickinson, 'Manus Island Trials' (1952) 38(2) Journal of the Royal Australian Historical Society 67, 70. Caroline Pappas discusses the trial in her doctoral thesis, Caroline Pappas, Law and Politics: Australia's War Crimes Trials in the Pacific, 1943-1961 (PhD Thesis, University of New South Wales, 1998). Michael Carrel discusses the disputed use of evidence in the Nishimura trial in Chapter 11 of his PhD thesis titled 'The Trials - Issues of Justice' highlighting problematic issues arising from the evidence used in the trials before concluding that 'on balance, the evidence would seem to suggest Nishimura's guilt': Michael Carrel, Australia's Prosecution of Japanese War Criminals: Stimuli and Constraints (PhD Thesis, University of Melbourne, 2005). Sir Gerard Brennan gives invaluable insights into aspects of the trial in a recent foreword: Brennan, above $\mathrm{n} 9$.

${ }^{11}$ Caroline Pappas, above n 10, 35, 42, 92. Pappas refers to the inherent difficulties posed, for political, jurisdictional and legal reasons, by Australia adopting trials pursuant to the British Royal Warrant 1945.See also United Nations War Crimes Commission, Law Reports of the Trials of War Criminals (His Majesty's Stationery Office, 1947) vol 1, 105; A P V Rogers, 'War Crimes Trials under the Royal Warrant: British Practice 1945-1949' (1990) 39 International and Comparative Law Quarterly 780, 786-7.

${ }^{12}$ War Crimes Act 1945 (Cth) ('War Crimes Act').

${ }^{13}$ Ibid preamble, ss 7, 12.

${ }^{14}$ Regulations for the Trial of War Criminals 1945 (Cth) ('War Crimes Regulations').

${ }^{15}$ Ibid.

${ }^{16}$ NAA: A472, W28681 - Letter from Commander-In-Chief T Blamey to Minister for the Army F Forde, 3 October 1945. 
held in the war crimes courts were clearly differentiated from field general courts-martial with respect to admissible evidence and maximum sentences. ${ }^{17}$ The Australian military authorities were vested with wide discretionary powers in regard to permissible forms of evidence. For the Australian authorities, the lowering of the evidentiary requirements assisted in expediting proceedings, given the difficulties in transporting witnesses to remote court locations around the Pacific region, and given also that in the post-War period witnesses may have died, or otherwise been unavailable to give oral testimony in court. $^{18}$

Part II of this article briefly outlines the background to the Nishimura trial. It then considers specific, and problematic, aspects of the trial that arose from the broad discretions exercised in the Australian war crimes courts. ${ }^{19}$ In Part III, the impact of the relaxed evidentiary standards on the conduct of the trial is examined. Part IV discusses Nishimura's death sentence, and issues raised during the post-trial processes. Part $\mathrm{V}$ summarises residual questions concerning aspects of the Nishimura trial. The article concludes that, in the Nishimura trial, the threshold for admissibility of evidence was too low and the maximum sentence of capital punishment too high. The examination of these factors arguably raises questions about the standard of justice reflected in Nishimura's trial.

\section{BACKGROUND TO THE NISHIMURA TRIAL}

\section{A The Charge}

Lieutenant-General Nishimura Takuma was charged with 'committing a war crime that is to say murder in that [he] at Parit Sulong in Malaya on the 22 Jan

\footnotetext{
${ }^{17}$ The late historian, David Sissons, who was a leading expert on the Australian war crimes trials, had previously written about criticisms that the War Crimes Act was 'discriminatory' against Japanese suspects in regard to the rules of evidence, death sentences and the confirmation process. See David Sissons, The Australian War Crimes Trials and Investigations (1942-1951), University of California, $19<\mathrm{http}: / /$ www.ocf.berkeley.edu/ changmin/documents/Sissons\%20Final\%20War\%20Crimes\%20Text\%2018-3-06.pdf>.

${ }^{18}$ NAA: MP742/1, 336/1/980 — Minute Paper titled 'War Crimes Trials’, 29 October 1946.

${ }^{19}$ Twenty-six trials were held at Manus Island out of an approximate total of 296 Australian war crimes trials: see, eg, Pappas, above n 10, 101; Sissons, above n 17, 19. See also Emmi Okada, 'The Australian Trials of Class B and C Japanese War Crimes Suspects, 1945-1951' (2009) Australian International Law Journal 47, 50-51. This article is a focused study on issues arising in the one selected trial, and, given the cited statistics, cannot be considered as broadly representative of the war crimes trials in their entirety.
} 
42 murdered a number of Australian and Allied Prisoners of War'. ${ }^{20}$ Nishimura was alleged to have ordered the execution of the captured prisoners of war. ${ }^{21}$ Section 3 of the War Crimes Act provided two definitions of war crimes. Pursuant to section 3(a), a war crime was defined as a violation of the laws and usages of war. ${ }^{22}$ The laws of war required that prisoners of war were to be treated humanely, and that a surrendered enemy soldier must not be arbitrarily executed. ${ }^{23}$ Section 3(b) of the Act also provided a list of war crimes that were in the remit of the Board of Inquiry - comprising Sir William Webb, Justice Alan Mansfield and Judge Richard Kirby — appointed on 3 September $1945 .^{24}$ While item (ii) of the Board of Inquiry’s list included 'murder and massacre, systemic terrorism', ${ }^{25}$ the charge against Nishimura clearly fell within the scope of section 3(a) of the War Crimes Act.

Captain Nonaka Shoichi was alleged to have assisted in the commission of the murders by passing on the order for execution to the officer in charge of the prisoners of war, Lieutenant Fujita Seizaburo. ${ }^{26}$ In an unfortunate turn of events, Fujita managed to abscond on 8 September 1949 while he was in the midst of being interrogated by members of the Australian War Crimes Section

${ }^{20}$ NAA: A471, 81942 - Record of Military Court — Nishimura and Nonaka, Précis of Evidence (emphasis added).

${ }^{21}$ Ibid.

${ }^{22}$ War Crimes Act s 3(a). As for the 'laws and usages of war', the Australian edition of the Manual of Military Law included written agreements and customary rules: Manual of Military Law (Commonwealth Government Printer, Australian ed, 1941). The list of agreements for Australian military forces included the Hague Convention IV Respecting the Laws and Customs of War on Land, opened for signature 18 October 1907, UKTS 9 (entered into force 26 January 1910) ('Hague Convention IV 1907'); Geneva Convention for the Amelioration of the Condition of the Wounded and Sick in Armies in the Field, opened for signature 27 July 1929, 118 LNTS 303 ('Red Cross Convention 1929'); Geneva Convention Relative to the Treatment of Prisoners of War, opened for signature 27 July 1929, 118 LNTS 343 (entered into force 19 June 1931) ('Prisoners of War Convention 1929') amongst others. During World War II, Japan was a party to the Hague Convention IV 1907 (as ratified by Japan on 13 December 1911) and Red Cross Convention 1929 (as ratified on 18 December 1934). Despite Japan not having formally ratified the Prisoners of War Convention 1929, Sir William Webb noted that Japan 'publicly undertook, shortly after the war broke out in the Pacific, to observe it generally on the basis of reciprocity', see NAA: A10943, item 1 - William Webb, A Report on War Crimes by Individual Members of the Armed Forces of the Enemy Against Australians, 15 March 1944, vol 1, 11.

${ }^{23}$ See, eg, Hague Convention IV 1907 art 4; Red Cross Convention 1929 art 3; Prisoners of War Convention 1929 art 3.

24 The Board of Inquiry was appointed pursuant to the National Security (Inquiries) Regulations, NAA: MP742/1, 336/1/382 - 'National Security (Inquiries) Regulations' issued by Attorney-General and Minister of State for External Affairs H V Evatt, 3 September 1945.

${ }^{25}$ Ibid.

${ }^{26}$ Ibid. 
in Japan. ${ }^{27}$ He subsequently eluded capture by the Japanese police, and was eventually removed from the charge sheet as the third-named accused. ${ }^{28}$

\section{B Nishimura's Defence}

At trial, Nishimura maintained his innocence. He argued that he had not given any orders for the execution of the prisoners of war. Rather, he argued that the order he had given was 'shobun seyo', meaning 'dispose of', and was intended by him to mean that the prisoners of war were to be evacuated to the rear. ${ }^{29}$ The accused gave evidence that if he had wanted the prisoners of war to be executed, he would have given the explicit order of 'shokei', meaning 'execute'. Nishimura submitted that his instructions were for the prisoners of war to be returned to the headquarters of General Yamashita, Commander of the $25^{\text {th }}$ Battalion and Nishimura's superior, ${ }^{30}$ which was some distance away.

\section{The Court}

Nishimura's trial was presided over by Brigadier Kenneth Townley, ordinarily a Judge of the Supreme Court of Queensland. ${ }^{31}$ The other court members were Lieutenant-Colonel N F Quinton, Major E J Gerling, Major H F Hayes and Major W E Clarke. ${ }^{32}$ Court members were experienced in matters of military service but were not required to have legal qualifications. Ad hoc appointments of judges-advocate were sometimes made to advise court members on points of law but this was not a compulsory requirement. ${ }^{33}$ In Nishimura's trial, no judge-advocate had been appointed. ${ }^{34}$ The Court did not issue written reasons for its findings, as was the practice of the war crimes courts. The absence of written reasons has contributed to the proliferation of varying interpretations and constructions of aspects of the trial.

\footnotetext{
${ }^{27}$ NAA: A471, 81942 — Affidavit of James Gowing Godwin, 20 October 1949.

28 NAA: A471, 81942 - Record of Military Court — Nishimura and Nonaka, Précis of Evidence.. See also NAA: M1505, 916 - Extract of Japanese Police Report, 1949.

${ }^{29}$ NAA: A471, 81942 - Transcript of Proceedings — Nishimura and Nonaka, sheet no 17.

30 Kyoichi Tachikawa, 'Yamashita and his Style of Leadership' in Brian Bond and Kyoichi Tachikawa (eds), British and Japanese Military Leadership in the Far Eastern War 1941-45 (Frank Cass, 2004) 75, 81.

31 NAA: A471, 81942 - Order for Assembly and Proceedings of a Military Court Nishimura and Nonaka, 23 May 1950.

32 Ibid.

${ }^{33}$ War Crimes Regulations reg 5.

34 NAA: A471, 81942 - Order for Assembly and Proceedings of a Military Court, 23 May 1950.
} 
The prosecuting counsel was Charles Rooney KC, and prosecuting officer Major H J Foster (Barrister and Solicitor, and Australian Army Legal Corps member) appeared as his junior. ${ }^{35}$ The sole Defence Advisory Officer was Major George Dickinson (Barrister, and Australian Military Forces officer), ${ }^{36}$ who assisted the Japanese defence counsel in all the trials at Manus Island. The allocated defence lawyer was Nakayama Choji, a lawyer with qualifications from Tokyo University. ${ }^{37}$ The Japanese interpreters allocated to the trial were Akio Honda, Michiomi Suwabe and a 'Mr Muramaru', alongside an Australian interpreter, Sergeant V Shaw. ${ }^{38}$

\section{THE IMPACT OF LOWER ADMISSIBILITY THRESHOLDS IN THE WAR CRIMEs CoURT}

War crimes courts were designed with very low admissibility standards for evidence, compared to the courts-martial and domestic courts with criminal jurisdiction of the period. ${ }^{39}$ Section $9(1)$ of the War Crimes Act provided:

At any hearing before a military court the court may take into consideration any oral statement or any document appearing on the face of it to be authentic, provided the statement or document appears to the court to be of assistance in proving or disproving the charge, notwithstanding that the statement or document would not be admissible in evidence before a field general court martial. ${ }^{40}$

Regulation 11 of the War Crimes Regulations stated that it 'shall be the duty of the Court to judge the weight to be attached to any evidence given in pursuance of section 9(1) of the Act which would not otherwise be admissible'. ${ }^{41}$ These evidentiary provisions enabled the war crimes courts to exercise an extremely broad discretion with regard to admissible evidence. The practical effect of section 9(1) and regulation 11 was that the prosecution

\footnotetext{
${ }^{35}$ NAA: A471, 81942 — Transcript of Proceedings — Nishimura and Nonaka, sheet no 2.

${ }^{36}$ Ibid.

${ }^{37}$ Ibid.

${ }^{38}$ Ibid.

39 NAA: A1066, H45/580/2 — Sir William Webb (Speech delivered at the International Relations Club in Queensland University, 26 June 1945). Webb’s opinion was that domestic court procedures were 'too slow, cumbersome and technical for the trial of war criminals'. Webb stated in his first report that should 'strict rules of evidence' apply, there would be problems with providing sufficient evidence, NAA: A10950, item 1 - William Webb, A Report on War Crimes by Individual Members of the Armed Forces of the Enemy Against Australians, 31 October 1944, vol 2, 2.

${ }^{40}$ War Crimes Act s 9(1).

${ }^{41}$ War Crimes Regulations reg 11.
} 
was permitted to present cases based on documentary evidence alone. No prosecution witnesses were called during Nishimura's trial, since prosecuting counsel tendered the written statements of witnesses at the commencement of trial, as permitted under the legislation.

The failure to call witnesses was problematic in this trial. In particular, questions arose as to the prosecution witnesses' identification of the accused, the inconsistencies in their testimony as to what Nishimura had said, and the fact that court members were not given the opportunity to evaluate the evidence and credibility of the witnesses in person.

\section{A Witness Ben Hackney}

The main prosecution witness in the trial was Lieutenant Ben Charles Hackney, an Australian soldier in the $2 / 29^{\text {th }}$ Battalion who had survived the Parit Sulong massacre. ${ }^{42}$ Hackney had been captured by the Japanese forces at Parit Sulong, and subjected to cruelty, torture and inhumane treatment. ${ }^{43} \mathrm{He}$ only survived the massacre by pretending to be dead. His first-hand account of the massacre thus formed a crucial element of the prosecution's case. Despite the potential force of his evidence, Hackney was not called as a witness at the trial. Instead, the prosecution principally relied upon his sworn affidavit.

Of the events leading up to the Parit Sulong massacre, Hackney stated in his affidavit that:

One of these new arrivals was outstanding and presumably the Commander of the Japanese Forces in the area - a short, stocky fellow ... He looked at the officer prisoners, who were made to move off the steps and stand ... Upon leaving the building he spoke to one of the officers accompanying him who in turn passed on what were apparently orders to the Jap [sic] in charge of the prisoners ... About sunset the guards began to move around the house. Machine guns were brought from where they had been resting between tours of duty and placed in front of the building. ${ }^{44}$

The prosecution used this evidence during the trial to suggest that the commander referred to was Nishimura. In August 1946, the 1 Australian War Crimes Section (based in Singapore) forwarded four photographs of Nishimura to Army Headquarters in Melbourne, requesting that they be

\footnotetext{
${ }^{42}$ NAA: A471, 81942 — Transcript of Proceedings, Nishimura and Nonaka, sheet no 4-6.

${ }^{43}$ NAA: A471, 81942 — Affidavit of Ben Charles Hackney, 12 November 1945.

${ }^{44}$ Ibid.
} 
produced to Hackney for identification purposes. ${ }^{45}$ Hackney was unable to positively identify Nishimura as the senior Japanese officer he had seen at Parit Sulong, ${ }^{46}$ and had referred to and described in his affidavit. ${ }^{47}$ Nishimura's prison file noted that he was five feet and five inches tall (about 1.65 metres), and weighed 147 pounds (about 66 kilograms). ${ }^{48}$ Yet, in his affidavit, Hackney had referred to a Japanese officer who was 'short' and 'stocky'. ${ }^{49}$ In this trial, Hackney's identification evidence was pivotal to the prosecution's case. The fact that it appears that the key prosecution witness was unable to positively identify Nishimura, and that there was no opportunity for the defence to cross-examine Hackney or for this information to be presented before the court, gives rise to concerns about this aspect of the trial.

On the other hand, Nishimura had not denied that he had been present at the scene of the Parit Sulong massacre at the relevant time. Under crossexamination, Nishimura conceded that he had inspected the prisoners of war. ${ }^{50}$ Nishimura's main line of defence was that his instructions had been incorrectly interpreted, and that he had not intended for the prisoners of war to be executed. However, while Hackney's affidavit identified one 'outstanding' presumed commander, it also referred to other senior Japanese officers, as well as soldiers, also present at the scene. ${ }^{51}$ These officers included the Chief

\footnotetext{
${ }^{45}$ NAA, MP742/1, 336/1/1962 - Memorandum from Australian Military Forces, 18 March 1946, where it is stated in relation to Nishimura and two other Japanese accused that '[i]mmediately upon their arrival the suspects will be photographed at full length for identification by Lieut. HACKNEY'. NAA, MP742/1, 336/1/1962 - Letter from 1 Australian War Crimes Section (SEAC) to Army Headquarters Melbourne, 2 August 1946 forwarding four photographs of Nishimura for production to Hackney 'to see whether he can identify NISHIMURA as the high ranking Officer who visited Parit Sulong immediately before the massacre took place' (capitalisation in the original).

${ }^{46}$ NAA: MP742/1, 336/1/1962 - Message from Army Melbourne to 1 Australian War Crimes Section (SEAC) stated in reference to the Parit Sulong war crimes, 'Hackney unable to identify Nishimura'. See also NAA, MP742/1, 336/1/1962 - Letter from 1 Australian War Crimes Section (SEAC) to War Crimes Investigation Team in Singapore, 14 October 1946, which requested an update on the interrogation of Nishimura and stated that Hackney could not identify Nishimura.

${ }^{47}$ NAA: MP742/1, 336/1/1962 — Letter from Lieutenant-General GOC Eastern Command to Army HQ, 24 September 1946. It was stated that Hackney was unable to identify Nishimura as the senior Japanese officer referred to in paragraphs 26-28 of his affidavit.

${ }^{48}$ NAA: B5563, 928 — Long Sentence Prisoner's Record — Nishimura.

${ }^{49}$ NAA: A471, 81942 - Affidavit of Ben Charles Hackney, 12 November 1945, 5.

${ }^{50}$ NAA: A471, 81942 - Transcript of Proceedings — Nishimura and Nonaka, sheet no 36.

${ }^{51}$ NAA: A471, 81942 - Affidavit of Ben Charles Hackney, 12 November 1945; Mant, above n 3, 33; NAA: MP742/1, 336/1/1962 - Report on the Parit Sulong Massacre by Lieutenant H P Leach, 1 December 1947; NAA: MP742/1, 336/1/1962 - Letter from OC 1 Aust War Crimes Sec (SEAC) to AHQ Melbourne, 6 November 1946. Preliminary investigations initially focused on Major-General Kobayashi Takashi, Commander of the Infantry Brigade, $2^{\text {nd }}$ Japanese Imperial Guards Division.
} 
of Staff of the Konoe Division, Colonel Imai Kamejiro, who was in charge of the prisoners of war, Staff Officer Supply, Major Morioka Eisaku, and Senior Adjutant, Major Toda Takeshi. ${ }^{52}$ Imai, Morioka and Toda had all died before the commencement of the trial. ${ }^{53}$ Given Hackney's inability to positively identify Nishimura, and the presence of other senior Japanese officers, the trial proceedings failed to test the presumption that it must have been Nishimura who had given the order to execute.

\section{B Witnesses Lieutenant Inagaki, Captain Hinokuma and Captain Sono}

Hackney's affidavit was not the only evidence tendered by the prosecution. The statements of three Japanese Armed Forces Officers, Lieutenant Inagaki Tadahiro, Captain Hinokuma Fukashi and Captain Sono Yoko, were also relied upon by the prosecution in its case against Nishimura. The evidence of the three Japanese witnesses was crucial to the court's reconstruction of what Nishimura had said at the scene, as Hackney could not understand Japanese and could not attest to this aspect of the prosecution case.

The prosecution adduced evidence from the three Japanese witnesses through their written statements. Inagaki, Hinokuma and Sono had given sworn statements in 1949 (the '1949 statements') to Captain James Gowing Godwin, an investigating officer in the 2 Australian War Crimes Section in Tokyo. ${ }^{54}$ In these statements, the officers had attested that they had witnessed Nishimura giving to Nonaka a verbal order for execution to pass to the officer in charge of the prisoners of war. The relevant portion of Inagaki's statement reads:

After Lieutenant-General Nishimura had stepped down off the porch and rejoined us other officers, he turned to Lieutenant Nonaka who was standing beside him and gave him, as far as I can now recall, the following oral order: 'Instruct the officer in charge of the prisoners of war' (rank and name was stated but I now cannot remember same) 'to execute all the prisoners of war by firing squad. ${ }^{55}$

The section in Hinokuma's statement reads:

\footnotetext{
52 NAA: A471, 81942 - Transcript — Nishimura and Nonaka, sheet no 16.

${ }^{53}$ NAA: A471, 81942 - Transcript - Nishimura and Nonaka, Closing Address of Defence. See also NAA: MP742/1, 336/1/1962 - Certified Copy of Report on Death of Imai Kamejiro (date of death 22 March 1947), 7 November 1949; NAA: MP742/1, 336/1/1962 — Certificate of Death of Toda Takeshi (date of death 30 January 1949), 17 September 1949.

${ }^{54}$ Silver, above $\mathrm{n} 4,304$.

${ }^{55}$ NAA: A471, 81942 - Statement of Inagaki Tadahiro, 3 October 1949 (emphasis added), 3.
} 
After Lieutenant-General Nishimura and others had stepped down from the porch and rejoined the other officers, he turned to his Personal Aide, Lieutenant Nonaka, and in the hearing of all the officers present, including myself, gave him, as far as I can now recall, the following oral order: 'Instruct the officer in charge of the prisoners of war' (rank and name was stated, but I now cannot remember same) 'to execute the prisoners of war in a suitable manner. ${ }^{56}$

Sono’s statement was to similar effect:

Almost immediately after Lieutenant-General Nishimura and others had descended the steps and rejoined us other officers, he turned to his Personal Aide Lieutenant Nonaka Shoichi who was standing near him, and in the hearing of all those officers present, including myself, gave him, as far as I can now recall, the following oral order: 'Instruct the officer in charge of the prisoners of war' (rank and name was stated but I now cannot remember same) 'to execute all the prisoners of war by firing squad. ${ }^{57}$

The 1949 statements contained similar passages, or slabs of evidence. On the one hand, the similarity of witness evidence may be proof that the accused did or said what the witnesses recalled. On the other hand, if witness evidence is remarkably similar, indeed almost identical, then the evidence may have been the result of coaching or coercion during interrogation. The impact of translation is another relevant factor, as it is also possible that during the translation process Australian investigating officers or translators may have used similar language to translate the respective statements. Upon later review of the evidence in 1950, Deputy Assistant Director of Legal Services at the Australian Military Forces Headquarters, Major Maxwell Ham, noted that sections of Hackney's evidence were mirrored in statements of other Japanese witnesses. ${ }^{58}$ Ham stated that in his opinion 'the marked similarity does lend considerable weight to the allegations made that the words were largely put into their mouths' by Godwin. ${ }^{59}$

In contrast to Ham's view, the subsequent opinion of the Judge-Advocate General, Supreme Court Justice William Ballantyne Simpson, was that the similarities across the witness statements resulted from Godwin using the standard interrogation procedures - in other words, Godwin would have unconsciously handled the matters using a methodology of chronological

\footnotetext{
${ }^{56}$ NAA: A471, 81942 — Statement of Hinokuma Fukashi, 18 October 1949 (emphasis added), 3-4.

${ }^{57}$ NAA: A471, 81942 - Statement of Sono Yoko, 14 October 1949 (emphasis added), 3.

58 NAA: MP742/1, 336/1/2137 — Letter from DADLS M Ham to AG Co-ordinator, 8 September 1950.

${ }^{59}$ Ibid.
} 
ordering. ${ }^{60}$ Silver too argues that Godwin used the standard process of interrogation, double translation, and arrangement into chronological order to produce the witness statements. ${ }^{61}$ The end result was a statement compiled by the investigator, and translated for the witness before signing and swearing. ${ }^{62}$ However, while the chronological ordering of statements addresses issues of form, it does not satisfactorily explain the content. The paraphrasing of statements by investigators, and the extent to which this was undertaken, does not adequately explain the high degree of consistency across the 1949 statements.

In an unusual set of circumstances, Nishimura's defence counsel also tendered statements that had subsequently been made by the same witnesses in 1950 (the '1950 statements'). These statements were tendered, peculiarly, in the trial's closing stages. While the witness statements reiterated that Nishimura had given a directive of sorts, the 1950 statements referred to an order to 'dispose of' the prisoners of war. ${ }^{63}$ This evidence differed from the witnesses' 1949 statements and their reference to an order to 'execute'. The 1950 statements were inconsistent with the 1949 statements, and also raise concerns about the credibility of the three Japanese witnesses.

The evidence of the Japanese witnesses was extremely important to the outcome of the trial because, as Major Ham stated, 'the whole matter of Nishimura's guilt depends on what he intended the word "Shobun” to signify. If he did not intend the prisoners to be executed, then the executions were the result either of a mistake or of wilful disobedience'. ${ }^{64}$ However, despite the 1949 and 1950 statements being inconsistent and arguably unreliable, the broad scope of section 9(1) of the War Crimes Act and regulation 11 of the War Crimes Regulations meant that the witnesses' sworn statements were unable to be closely examined in court. If these key witnesses had been called to give testimony at the trial, their evidence would have been subject to the rigours of cross-examination.

\footnotetext{
${ }^{60}$ NAA: MP742/1, 336/1/2137 — Letter from Judge-Advocate General Simpson to Adjutant General, 12 September 1950.

${ }^{61}$ Silver, above $\mathrm{n}$ 4, 377.

${ }^{62}$ Ibid.

${ }^{63}$ NAA: A471, 81942 - Statement of Inagaki Tadahiro, 14 March 1950; NAA: A471, 81942 - Statement of Hinokuma Ryo, 18 March 1950; NAA: A471, 81942 - Statement of Sono Yoko, 13 March 1950. Inagaki attributed both orders for disposal and cremation to Nishimura whilst Hinokuma and Sono stated Nishimura gave the first order and Imai then ordered the cremation.

${ }^{64}$ NAA: MP742/1, 336/1/2137 - Letter from DADLS Maxwell Ham to AG Co-ordinator, 8 September 1950.
} 
Nishimura's defence counsel, Nakayama, stated in his closing address that '[t]his case, which has exhibited to the fullest extent the defects of this trial by documentary evidence, is on a high level ... the evidence is not material evidence, it is mere hearsay of witnesses, and lacks accuracy, which anyone connected with Court procedure is well aware [sic]'. ${ }^{65}$ Nakayama's statement, while put forward in support of his clients' case, also highlights inherent problems with prosecuting trials on documentary evidence alone. Whereas this practice enables the expeditious conduct of trials, it also compounds the difficulties in the conduct of the defence cases for the accused. In this case, while the standard of proof remained 'beyond reasonable doubt', in practice, the lower admissibility thresholds effectively shifted the burden of proof onto defence teams. ${ }^{66}$ As the prosecution could present cases on documentary evidence alone, the onus of proof then shifted to the defence lawyers and accused, who had to attempt to refute the admissibility, or disprove the authenticity, of the documentary evidence - in the absence of the oral testimony of witnesses. Japanese defence lawyers were already faced with language and cultural barriers, unfamiliarity with Australian military courts and common law principles, and comparatively short timeframes for preparation. Dickinson described the Japanese lawyers as being inexperienced and lacking in guile. ${ }^{67}$

Moreover, the court's ability to ascertain and accord appropriate weight to evidence was affected by the absence of witnesses appearing in person to assist in this process. As witnesses were not called to testify during the trial, whether the evidence was genuine, conspiratorial, coerced or misinterpreted was not properly tested.

\section{Nishimura's Death Sentence, Petitions and the CONFIRMATION PROCESS}

On 22 June 1950 the war crimes court found Nishimura guilty and sentenced him to death by hanging. ${ }^{68}$ The evidentiary issues raised in Part III should be considered in the context of the court's sentencing range. It is argued that the lower admissibility thresholds combined with the option of capital

${ }^{65}$ NAA: A471, 81942 - Transcript of Proceedings - Nishimura and Nonaka, Closing Address of Defence, 2.

${ }^{66}$ NAA: MP742/1, 336/1/980 - Letter from Sir William Webb to Minister for the Army F Forde, 8 January 1946.

${ }^{67}$ See Dickinson, 'Japanese War Trials', above n 9, 70; Dickinson, 'Manus Island Trials', above n 10, 70 .

${ }^{68}$ NAA: A471, 81942 - Transcript of Proceedings - Nishimura and Nonaka, sheet no 101; NAA: A471, 81942 - Record of Military Court - Nishimura and Nonaka, Précis of Evidence; NAA: A471, 81942 — Warrant of Execution — Nishimura, 11 June 1951. 
punishment were inherently problematic in this trial. Pursuant to section 11(1) of the War Crimes Act, the court was empowered to impose death sentences on convicted war criminals. Section 11(1) provided:

A person found guilty by a military court of a war crime may be sentenced to and shall be liable to suffer death (either by hanging or by shooting) or imprisonment for life or for any less term; and, in addition or in substitution therefor, either confiscation of property or a fine of any amount, or both. ${ }^{69}$

This was a broad power that exceeded the powers of standard courts-martial as such courts could not sentence an Australian soldier to death except for specified offences arising from traitorous or mutinous conduct. ${ }^{70}$

There was no option of appealing Nishimura's death sentence to an independent judicial body as the war crimes courts were military courts, and military courts did not have an appellate mechanism. Under the War Crimes Act, the Governor-General's powers to confirm or order revision of findings, mitigate, commute or remit sentences, and defer executions, could be delegated. $^{71}$ In this particular case, these powers were delegated to AdjutantGeneral Major-General Warren Melville Anderson. The nature and scope of the war crimes delegations were distinguishable from those applicable at standard courts-martial as death sentences imposed on Australian soldiers could only be confirmed by the designated civil authority, the GovernorGeneral in Council. ${ }^{72}$ After concerns were raised in 1945 by the Secretary of the Department of the Army, Frank Roy Sinclair, over the confirmation procedure, the Chifley Government decided that death sentences in war crimes cases were to be referred to the Judge-Advocate General - a civil authority with legal expertise - for advice prior to the Adjutant-General being able to confirm any sentences. ${ }^{73}$

Nishimura's post-trial confirmation was exceptional as it deviated substantially from the normal process, as will be outlined below, and ultimately it was Cabinet that endorsed his death sentence.

\footnotetext{
${ }^{69}$ War Crimes Act s 11(1). At the time, international law permitted death sentences for war crimes and section 11 was not unique to the Australian jurisdiction. For instance, the International Military Tribunals at Nuremberg and Tokyo were authorised to sentence convicted war criminals to death. See William A Schabas, The Abolition of the Death Penalty in International Law (Cambridge University Press, $3^{\text {rd }}$ ed, 2002) 263, 240.

${ }^{70}$ Defence Act 1903-1939 (Cth) ('Defence Act') s 98.

${ }^{71}$ War Crimes Act ss 5, 6.

${ }^{72}$ Defence Act s 98. See also Sissons, above n 17, 16.

${ }^{73}$ Sissons, above $\mathrm{n} 17,16-17$. Prior to the delegation of the power to confirm death sentences to the Adjutant-General on 23 April 1947, the Commander-in-Chief had exclusive authority. See, eg, Carrel, above n 10, 86. See also Pappas, above n 10, 46-8.
} 


\section{A The First Petitions}

On 29 June 1950, Nishimura and Nakayama filed petitions against the finding and sentence (the 'first petitions'). Nishimura petitioned on various grounds: that the charge against him was false, the trial relied too heavily on documentary evidence, and he would never have given an order to execute by firing squad. ${ }^{74}$ Nishimura submitted that during his 40 years in the Japanese Army he had never been taught to give such an order. ${ }^{75}$ Nishimura also maintained that he should have been given more time in Japan to gather evidence for his defence, and that he had not had reasonable time to prepare, given that he had been held in custody in Singapore prior to being transported to Manus Island for trial. ${ }^{76}$ He claimed that the first time he became aware of the charge against him was aboard a transit ship to Manus Island on 21 May $1950 .{ }^{77}$ Despite this, at the commencement of the trial, when the court asked whether defence counsel wished to apply to adjourn the matter on grounds including the ground that insufficient time had been given for defence preparation, Nakayama replied in the negative. ${ }^{78}$

Judge-Advocate General Simpson, who subsequently considered the first petitions, agreed with the court's findings. ${ }^{79} \mathrm{He}$ concluded that 'from the written evidence tendered by the prosecution it will be seen that there was ample evidence to justify a conviction if the court saw fit to accept such evidence as accurate'. ${ }^{80}$ Upon Judge-Advocate General Simpson's advice, Adjutant-General Anderson confirmed the finding and sentence in Nishimura's case on 7 August $1950 .{ }^{81}$

\footnotetext{
${ }^{74}$ NAA: A471, 81942 - Petition from Nishimura Takuma to Confirming Officer, 29 June 1950.

${ }^{75}$ Ibid.

${ }^{76}$ NAA: A471, 81942 - Petition from Nakayama Choji to the Confirming Officer, 29 June 1950.

${ }^{77}$ Ibid. Nishimura had been serving time in Changi when the Australian Military Forces requested that he be transferred to Hong Kong by 6 April 1950, and then to Manus Island: NAA: MP742/1, 336/1/1096 - Cipher Message from Army Melbourne to 2 Aust War Crimes Sec Tokyo, 18 February 1950. See also NAA: A471, 81942 - Transcript of Proceedings - Nishimura and Nonaka, sheet no 14, wherein Nishimura stated that it was en route from Hong Kong to Manus Island that he first learnt of his charges, and that he would be tried at a war crimes court. (He reached Manus Island less than one month before his trial was to commence.) The Prisoners of War Convention 1929 art 6 stipulated that notification should be given 'as soon as possible' before hearing, with particulars regarding the court/date/place to be delivered more than three weeks beforehand.

${ }^{78}$ NAA: A471, 81942 - Transcript of Proceedings - Nishimura and Nonaka, sheet no/s 2-3.

${ }^{79}$ NAA: A471, 81942 — Letter from the Judge-Advocate General to Adjutant-General, 21 July 1950.

${ }^{80}$ Ibid.

${ }^{81}$ See, eg, NAA: A471, 81942 — Confirmation by Adjutant-General Anderson, 7 August 1950.
} 


\section{B The Second Petition}

After the finding and sentence were confirmed, on 18 August 1950, Nakayama filed a second Notice of Petition (the 'second petition') requesting a new trial on the grounds of fresh evidence. ${ }^{82}$ Nakayama argued that there had been a miscarriage of justice, and sought to have his client's Warrant for Execution postponed. ${ }^{83}$ He referred to new statements obtained from the three Japanese witnesses, Inagaki, Hinokuma and Sono (the 'new statements'). It was alleged that their original evidence had been obtained by 'leading questions, intimidation and suggestion, and was distorted by the investigating officers, and raise[d] a serious doubt concerning the truth and probative value of the testimony contained in the original affidavits' ${ }^{84}$ The new statements, which had been made after the 1949 and 1950 statements, were used in support of the defence's submission that the evidence was unreliable. ${ }^{85}$

As outlined in Part III of this article, on 8 September 1950, Major Ham examined the second petition. Ham referred to the Judge-Advocate General's earlier review of the first petitions when he noted that there was 'no substantial miscarriage of justice so far as the proceedings themselves are concerned' ${ }^{86}$ The key issue, Ham noted, was the effect of the subsequent material forwarded in support of the second petition - namely, the new statements from the three witnesses. Ham underscored the similarities across the witness statements, and noted in particular that sections of Hackney's affidavit were 'closely reflected' in the evidence of the Japanese witnesses. ${ }^{87}$ Upon examination of the similarities in the 1949 statements, he noted two possibilities: either that Godwin, 'being thoroughly conversant with what

${ }^{82}$ NAA: MP742/1, 336/1/2137 - Petition for a New Trial from Nakayama Choji, 18 August 1950. Nakayama had received some advice from Ben Bruce Blakeney, NAA: MP742/1, 336/1/2137 - Letter from Nakayama Choji to the Commanding Officer, 31 July 1950; NAA: MP742/1, 336/1/2137 - Letter from Ben Blakeney to Nakayama Choji, 5 July 1950. Blakeney was an eminent American defence lawyer who had worked on the Tokyo Trial. See Pappas, above $\mathrm{n} 10,76$.

${ }^{83}$ NAA: MP742/1, 336/1/2116 - Memorandum from Lieutenant-Colonel A L MacDonald, 15 September 1950.

${ }^{84}$ Ibid.

${ }^{85}$ NAA: MP742/1, 336/1/2137 - Statement of Inagaki Tadahiro, 12 July 1950. A detailed account was provided by Inagaki prior to his conclusion: 'I cannot say my deposition of that time was absolutely right, because it was made under such circumstances I mentioned above'; NAA: MP742/1, 336/1/2137 - Statement of Sono Harumitsu, 11 July 1950, 'I was subjected to mental pressure very hard by his attitude and these languages to me [sic]'; NAA: MP742/1, 336/1/2137 - Statement of Hinokuma Fukashi, 13 July 1950 also referred to leading questions. Hinokuma alleged that Godwin had said to him '[i]f you will not answer me quickly, you shall not be permitted to go home for ever'.

${ }^{86}$ NAA: MP742/1, 336/1/2137 — Letter from DADLS Maxwell Ham to AG Co-ordinator, 8 September 1950.

${ }^{87}$ Ibid. 
Lieut Hackney had said more or less put the words into the mouths of the three Japanese', or that the facts had an indelible impact on the witnesses. ${ }^{88}$ Major Ham acknowledged the 'tendency' for accused to make accusations of improper conduct against interrogators during the war crimes trials. But, given the 'marked similarity' across the 1949 statements, Nishimura's denials of guilt, and the weight placed on the evidence of the Japanese witnesses in the prosecution's case against him, Ham concluded that there existed a 'reasonable doubt that there may have been a miscarriage of justice and as the life of a man depends on the matter being correctly evaluated I think that such action should now be taken'. ${ }^{89}$ The case was re-submitted to the JudgeAdvocate General.

Subsequently, Judge-Advocate General Simpson advised that the differences in the statements, and Godwin's use of chronological ordering, were sufficient reasons to find that the 1949 statements were valid. ${ }^{90}$ In Simpson's opinion, the new statements did not constitute fresh evidence given that they could have been obtained during the trial, and that no miscarriage of justice had occurred. ${ }^{91}$ He advised that there were no grounds for a new trial.

In an exceptional set of circumstances, Adjutant-General Anderson referred the case on to the Solicitor-General, Professor Kenneth Bailey, for his opinion in October 1950. ${ }^{92}$ Like Ham, Bailey concluded that there were issues that warranted the re-examination of the Nishimura trial. Comparing the 1949 statements with the subsequent statements, Bailey noted that the 'general effect of the new statements is that the original statements were not voluntary as the law understands the term, and if believed they do seem to throw doubt on the evidence as to what orders were given'. ${ }^{93}$ In his view the allegations made by the three witnesses and Nonaka as to the interrogatory methods used by Godwin, in conjunction with the marked similarities across the statements, raised questions about the voluntariness of the 1949 statements. As for the trial being presented on documentary evidence alone, Bailey thought that

\footnotetext{
${ }^{88}$ Ibid.

${ }^{89}$ Ibid.

90 NAA: MP742/1, 336/1/2137 - Letter from Judge-Advocate General Simpson to the Adjutant General, 12 September 1950.

${ }^{91}$ Ibid. The allegations had not been adduced at trial. Judge-Advocate General Simpson had relied upon the High Court of Australia case of Green $v$ The King (1939) 61 CLR 167 for the test for ascertaining fresh evidence. The war crimes courts were not civil courts and the military structure did not provide for the avenue of appeal. The war crimes courts had been established to avoid such technicalities as strict procedural and evidentiary requirements.

92 NAA: M1505, 916 - Letter from Adjutant-General W Anderson to Solicitor-General K Bailey, 3 October 1950.

${ }^{93}$ NAA: M1505, 916 — Document titled 'The Case of Nishimura', 2.
} 
the method of trial precluded certain advantages normally vouchsafed to the accused, and this consideration invites special caution in accepting any conclusion upon which doubt may be thrown, particularly in a case where the sentence is death. ${ }^{94}$

The Solicitor-General concluded that there was scope in the War Crimes Regulations to conduct further investigation. ${ }^{95}$ Regulation 20, for example, gave the court an overarching discretion to adopt a course 'as appears best calculated to do justice'. ${ }^{96}$ While correspondence indicates that the SolicitorGeneral had not responded to Adjutant-General Anderson as of February $1951,{ }^{97}$ and his written report was not formally submitted, the two men had discussed the matter. ${ }^{98}$

The defence filing of Nishimura's second petition in August 1950 exceeded the 14 day time limit after the court's findings. Pursuant to the March 1951 recommendations of the Attorney-General, John Spicer, the case was treated as an application for remission pursuant to regulation 19 of the War Crimes Regulations, and referred back to Presiding Judge Townley. ${ }^{99}$ Judge Townley subsequently advised that there was no reason to remit the case because if the evidence had been presented at trial it would not have resulted in the variation of Nishimura's sentence. ${ }^{100}$ Two of the original court members, LieutenantColonel Quinton and Major Gerling, were in agreement with Townley; Majors Hayes and Clarke were unavailable for consultation. ${ }^{101}$ On 4 May 1951, Judge-Advocate General Simpson advised Adjutant-General Anderson that the finding and sentence should again be confirmed. ${ }^{102}$

\section{Petitions Submitted to Cabinet}

In another atypical turn of events, Cabinet became involved in the case. Cabinet had been involved in selecting the list of trials for Manus Island, and

\footnotetext{
94 Ibid.

95 Ibid, in reference to War Crimes Regulations regs 19-20.

${ }^{96}$ Ibid. War Crimes Regulations reg 20 applied where cases arose that were not provided for in the Regulations.

97 NAA: M1505, 916 - Letter from Minister for the Army J Francis to Attorney-General J Spicer, 12 February 1951.

${ }^{98}$ Pappas, above n 10, 77.

99 NAA: M1505, 916 - Letter from Attorney-General J Spicer to Minister for the Army J Francis, 14 March 1951.

${ }^{100}$ NAA: MP742/1, 336/1/2137 — Letter from President Townley to the Adjutant General, 30 March 1951.

101 Ibid.

102 NAA: MP742/1, 336/1/2137 — Letter from Judge-Advocate General W B Simpson to Adjutant-General Anderson, 4 May 1951.
} 
had prior knowledge of the cases. Petitions for mercy on behalf of various accused sentenced to death at Manus Island were made to Prime Minister Robert Menzies by the Holy See and Asai Kenkyo, a Buddhist priest based at Manus Island. ${ }^{103}$ Nishimura, as he was awaiting the death sentence at Manus Island, was included in the group that was the subject of Asai's petition. ${ }^{104} \mathrm{~A}$ submission regarding the petitions was then referred to Cabinet by the Australian Military Forces. ${ }^{105}$ The Menzies government publicly announced its decision to endorse the death sentences of Nishimura and three other convicted war criminals by way of a press statement dated 30 May 1951. ${ }^{106}$ The high-level political involvement in confirming these death sentences was an extremely rare occurrence that was confined to the Manus Island proceedings, and was largely prompted by the involvement of the aforementioned external petitioners. Nishimura was executed at Manus Island on 11 June $1951,{ }^{107}$ and buried at sea. ${ }^{108}$

\section{Residual Questions}

As outlined in this article, there are aspects of the trial that trouble this author and others. One problem is that Lieutenant Fujita managed to abscond midway through interrogation, resulting in the absence of the third co-accused from the trial. ${ }^{109}$ His unsworn statement that Nishimura's order was for execution appeared to conflict with the evidence of Nishimura and Nonaka, and Fujita's evidence may have therefore been pivotal. ${ }^{110}$ At various points it

\footnotetext{
${ }^{103}$ NAA: A4905, 1 - Letter from Apostolic Delegation to Prime Minister Menzies, 11 April 1951; NAA: A4905, 1 - Petition of Asai Kenkyo to Prime Minister Menzies, 9 April 1951; NAA: A4905, 1 - Note on Cabinet Submission No 1: Death Sentences Imposed by the War Crimes Court Manus Island, 10 May 1951. In addition, the Secretary of the YMCA in Japan communicated with the government, seeking to have the death sentences commuted to life imprisonment and for the prisoners to be paroled to Japan. See also NAA: MP742/1, 336/1/2137 - Petition from Nakayama Choji to the Confirming Officer, 4 April 1951. This was the third petition submitted, and included a sworn statement of Nakayama Shikao (Nishimura's former cellmate in Hong Kong prior to arrival in Manus Island), 8 March 1951. This petition reiterated the points that Nakayama had raised in his previous two submissions and was refused.

104 NAA: A4905, 1 - Petition of Asai Kenkyo to Prime Minister Menzies, 9 April 1951, referring to the ' 12 persons who were sentenced to death by hanging'.

${ }^{105}$ Carrel, above n 10, 178.

${ }^{106}$ NAA: A471, 81942 - Prime Minister of Australia — Death Sentences of Japanese War Criminals (Press Statement, 30 May 1951). See also Carrel, above n 10, 178.

107 NAA: A471, 81942 - Warrant of Execution - Nishimura, 11 June 1951; NAA: A471, 81942 - Certificate by Officer Supervising the Execution, 11 June 1951.

${ }^{108}$ Mant, above n 3, 8.

${ }^{109}$ NAA: M1505, 916 - Extract of Japanese Police Report, 1949.

110 NAA: A471, 81942 - Interrogation Record of Fujita Seizaburo, 6-7 September 1949; NAA: A471, 81942 - Petition from Nonaka Shoichi to Confirming Officer of the Australian
} 
was implied that Fujita may have made a mistake in interpreting the order, ${ }^{111}$ but given the dropping of charges against him and his absence from the courtroom such allegations could not hold much weight.

The Australian Military Forces correspondence indicating that Hackney was unable to positively identify Nishimura is another troubling factor. There may be reasonable explanations for this, but it should be highlighted as an anomaly at the very least. Hackney had been severely wounded and ill-treated during the massacre, and witnesses are not always able to recollect every moment of an incident or particulars of every individual involved. But given the vividness and level of detail of Hackney's account, and given that his evidence was pivotal to the prosecution's case, the fact that he was later unable to positively identify Nishimura naturally stands out. Furthermore, the prosecution of the case on documentary evidence meant that the defence could not cross-examine Hackney on the contents of his affidavit.

The degree of consistency across the three witness statements, and the allegations made by various Japanese officers, also raise questions about the voluntariness of evidence. If the defence counsel had requested that Inagaki, Hinokuma and Sono be called as witnesses - it would certainly have assisted in clarifying key evidence. However, it appears doubtful that the request would have been granted given the amount of extra time and resources required, and because their appearance as witnesses was technically not required under the War Crimes Act.

During the trial, Nakayama did not seek to call any witnesses on behalf of Nishimura or Nonaka. ${ }^{112}$ Given that the life of a prisoner was at stake, it seems extraordinary that Nakayama did not even attempt to call witnesses. ${ }^{113}$ Also, the allegations raised by Nonaka in regard to Godwin's interrogation methods could have been raised with the three Japanese witnesses for inclusion in their additional statements tendered at trial. (It was evident that Godwin had interrogated Nonaka, Inagaki, Hinokuma and Sono.)

Army Legal Corps, 4 July 1950: 'The Aide then came over to me and said, "it is in the General's order that you execute all the prisoners of war" or words to that effect. After the General and his staff officers had left I caused the prisoners of war to be executed by machine gun and rifle fire.'

${ }^{111}$ NAA: A471, 81942 — Transcript of Proceedings — Nishimura and Nonaka, sheet no 18; NAA: A471, 81942 - Petition from Nonaka Shoichi to Confirming Officer of the Australian Army Legal Corps, 4 July 1950 where Nonaka alleged that Fujita had misinterpreted Nishimura's command of 'shobun seyo' to mean 'execute' them.

${ }^{112}$ NAA: A471, 81942 - Transcript of Proceedings - Nishimura and Nonaka, sheet no 10.

${ }^{113}$ NAA: MP742/1, 336/1/2137 — Petition from Nakayama Choji to the Confirming Authority, 4 April 1951, where Nakayama later admitted to his own 'carelessness' in failing to summons the witnesses. 
Furthermore, the subsequent petitions submitted on behalf of Nishimura were, after the initial unsuccessful petition, technically out of time. As previously noted, the Japanese defence teams faced numerous difficulties in the preparation of their cases, but in many respects Nakayama's defence work could be criticised for lacking the requisite forcefulness required in those circumstances.

Another issue arises from the fact that, although the conduct of the trial was independently examined by Major Ham and Professor Bailey, who both concluded that Nishimura's case warranted re-examination, this did not occur. Professor Bailey, as Solicitor-General, was an academic and one of Australia's most senior legal officers. On the other hand, Brigadier Townley and Judge-Advocate General Simpson were both Supreme Court judges and also had the benefit of experience in the sphere of military justice. However, both Professor Bailey and Major Ham raised concerns about aspects of the Nishimura trial. Given Professor Bailey's legal standing, and Major Ham's military and legal background as Assistant Director of Legal Services, their opinions should also have carried weight.

In this author's opinion, these issues raise doubts as to whether the outcome of the trial can be regarded as wholly conclusive. The discrepancies and ambiguities, if considered in their entirety, raise doubts, and such doubts are significant when the guilt of an accused sentenced to death on a charge of murder is in question. The war crimes legislation incorporated a catch-all provision in regulation 20 that enabled the court to adopt any necessary measures in the dispensation of justice, which in this case, should have been used to conduct further investigations.

It is, however, certainly arguable that Nishimura had some degree of culpability. The fact that Nishimura had been present at the scene is not disputed. Nishimura was General Officer Commanding and therefore responsible for the command of subordinates of various rankings. Putting aside the debates about the actual order given and the intention behind the order, Nishimura himself admitted that he gave the order of 'shobun seyo'. The Japanese military code, and strict adherence to orders given by superiors on behalf of the Emperor, ${ }^{114}$ placed the utmost responsibility on commanders for the conduct of their subordinates. At the trial's close, Nishimura told the court, 'I am very sorry that due to my carelessness in this case such an incident as this happened. I wish to give praise with sorrow to those who were killed in this case. That is all'. ${ }^{115}$ In this closing statement he admitted to his

\footnotetext{
114 Yuki Tanaka, Hidden Horrors: Japanese War Crimes in World War II (Westview Press, 1996) 201-2.

${ }^{115}$ NAA: A471, 81942 — Transcript of Proceedings — Nishimura and Nonaka, sheet no 93.
} 
own 'carelessness' in the matter. The fact that Nishimura had failed to exercise proper supervision of his subordinates was also conceded by Nakayama in a subsequent petition. ${ }^{116}$ The prosecuting counsel's closing address referred to the failure of Nishimura to either conduct a subsequent enquiry or to punish his subordinates for the executions. ${ }^{117}$ The prosecuting counsel's references to Nishimura's failures correlate with certain elements of the doctrine of command responsibility. ${ }^{118}$ At the time of the post-World War II trials, the legal concept of command responsibility was evolving in international law and it was applied in cases involving other senior Japanese officers in the Australian war crimes courts. ${ }^{119}$

An Australian Military Forces file note dated 1949 referred to inadequate evidence for a direct charge of participation but highlighted Nishimura's exposure to a charge of command responsibility. ${ }^{120}$ In contrast, notes drafted in 1945 after General Yamashita's interrogation, indicated that a case could be made out against Nishimura for ordering the executions. ${ }^{121}$ Ultimately, the case was prosecuted on the ground that Nishimura had ordered that the prisoners of war be executed. However, as outlined in this article, problems arose in the construction of evidence regarding Nishimura's relevant orders. In practical terms, it may have been difficult for the Australian Military Forces to have prosecuted a charge of command responsibility given the inability of authorities to locate Fujita, and the deaths of Imai, Morioka and Toda. Possibly another consideration for why command responsibility was not used in the Nishimura trial was that the massacre was confined to Parit Sulong and not dispersed over a wide geographical area, or that the Australian authorities considered their case against Nishimura for ordering the executions as clear-cut. Theoretically, command responsibility was a plausible

\footnotetext{
${ }^{116}$ NAA: A471, 81942 — Petition from Nakayama Choji to the Confirming Officer, 29 June 1950.

117 NAA: A471, 81942 - Transcript of Proceedings - Nishimura and Nonaka, Closing Address of Prosecution, 3.

${ }^{118}$ For detailed discussion of the elements of command responsibility (also referred to as 'superior responsibility') in historical and contemporary contexts, see, eg, Gideon Boas, James L Bischoff and Natalie L Reid, Forms of Responsibility in International Criminal Law (Cambridge University Press, 2007); Guénaël Mettraux, The Law of Command Responsibility (Oxford University Press, 2009); Andrew Mitchell, 'Failure to Halt, Prevent or Punish: The Doctrine of Command Responsibility for War Crimes' (2000) 22 Sydney Law Review 381.

${ }^{119}$ See, eg, Pappas, above n 10, 237, 255.

${ }^{120}$ NAA: MP721/1, 336/1/1962 — File note of Major H Dick, 4 April 1949. Lack of positive identification was cited as the reason for 'inadequate evidence' although the file note was drafted some six months prior to the interrogation of the three Japanese witnesses.

${ }^{121}$ NAA: MP721/1, 336/1/1962 — Notes of Proposed Interrogation of Japanese General Officers in Japan by Major C Wild, 9 November 1945. The notes suggested that the interrogating officer 'should assume as a fact that NISHIMURA was the senior officer in question' (capitalisation in the original).
} 
form of criminal liability that could have been used in the charge/s against Nishimura, and one that was supported by the undisputed facts of the matter.

\section{Conclusion}

The various problems in the trial of Lieutenant-General Nishimura arose from the extremely broad discretion granted to the court to permit evidence to be adduced before it, and from the application of the death sentence. Section 9(1) of the War Crimes Act effectively allowed cases to be prosecuted entirely on documentary evidence. In practice, this meant that key witnesses in the Nishimura trial such as Lieutenant Hackney, Lieutenant Inagaki, Captain Hinokuma and Captain Sono were not required to give oral testimony in court. The ambiguities and inconsistencies arising in witness evidence particularly with regard to Hackney's inability to identify Nishimura and the three Japanese witnesses' conflicting evidence on what order Nishimura had given — were unable to be tested before the court.

In contrast to a standard court-martial, the Los Negros court was able to hand down death sentences for a wide range of war crimes. The legislative and regulatory frameworks governing the trial of war crimes, like those governing military courts but unlike those governing domestic courts vested with criminal jurisdiction, did not include an independent appeals channel. Furthermore, the war crimes court differed from a standard court-martial in that the authority vested with the power to confirm death sentences was, in this particular case, the Adjutant-General. In Nishimura's case, the petitions were considered by Adjutant-General Anderson and Judge-Advocate General Simpson. The unusual circumstances in this case included the referral of the matter to Solicitor-General Bailey, and, formally, to Cabinet for final approval. (The involvement of the external petitioners warranted the highlevel political involvement.) There was majority consensus that the findings should be confirmed, but the two contrasting opinions given by Major Ham and Professor Bailey are indicative of the problematic aspects of the trial.

The war crimes legislation enabled the trials of Japanese accused in military courts, with the overarching purpose being the implementation of postconflict justice for war crimes committed against Australian, Allied and associated forces during World War II. The war crimes courts, under the legislation, exercised broad discretion in regard to the admissibility of evidence and the choice of sentence. This enabled the expeditious conduct of proceedings. These objectives were precariously balanced, at times, against the need to ensure justice for the accused and the requirement that guilt be proven beyond a reasonable doubt. This precarious balance can be seen in the Nishimura trial. Questions about the degree of justice achieved by this case 
are raised by a combination of, first, the prosecution of the case wholly on documentary evidence; second, the application of low admissibility thresholds; third, the questionable voluntariness and reliability of witness evidence; and, last, the fact that the death penalty was imposed.

It is acknowledged that the trial was conducted at a time and in a type of forum far removed from contemporary fair trial principles. It is true that the Australian authorities ensured that Nishimura was assisted by defence counsel, that adjournments might have been permitted if his counsel had made such requests to the court, and that numerous petitions by the accused over a one year period were considered. But in a method of trial where the floor for admissible evidence is set too low, and the ceiling of capital punishment placed too high, there is more opportunity for problems to arise in the pursuit of justice. Whilst more than 60 years have passed since this trial commenced, it is arguable that certain aspects of the Nishimura case remain open to debate to this very day. 